\title{
PRINCEZNY Z HÁJKU. \\ K PROBLEMATICE ELITY VE STŘEDNÍ DOBĚ BRONZOVÉ
}

\section{Soňa Nožinová* - Petr Krištuf*}

\author{
*Katedra archeologie, Fakulta filozofická, Západočeská univerzita v Plžni, Sedláckova 15, 30100 Plžñ̌, Česká republika, \\ sona.nozinova@seznam.cz,pkristuf@kar.zcu.cz.
}

\begin{abstract}
Princesses from Hájek. On the Issue of the Middle Bronze Age Elite. The topic of this study is the possibilities of archaeological identification of the local elite in the Bronze Age. We're targeting the female elite, who are characterized by a particular form of costume. In a case study of the barrow cemetery of Št áhlavy - Hájek, we are trying to show that the elite status of women in the Bronze Age was not based on their personal qualities, but rather on their affinity with an elite family. Their social status may therefore have been hereditary. On the other hand, it turns out that certain particularities of the costume (different types of necklaces, etc.) may point to different origins of women and thus the exchange of female partners within the wider elite community.
\end{abstract}

Keywords: costume, elite, jewellery, women, bronze age, barrow cemetery, Št’áhlavy - Hájek

Abstrakt: Tématem této studie jsou možnosti archeologické identifikace lokální elity v době bronzové. Zaměřujeme se na ženskou elitu, která se vyznačuje specifickou podobou kroje. Na konkrétním př́ikladě mohylového pohřebiště Št'áhlavy - Hájek se snažíme ukázat, že elitní postavení žen v době bronzové nevycházelo z jejich osobních kvalit, ale spíše z jejich spř́zznění s elitní rodinou. Takové postavení mohlo být dědičné. Zároveň se však ukazuje, že určitá specifika kroje (odlišné typy náhrdelníků a pod.) mohou ukazovat na odlišný původ žen a tím pádem výměnu partnerek v rámci širší komunity elit.

Klíčová slova: kroj, elita, šperky, ženy, doba bronzová, mohylové pohřebiště, Št’áhlavy - Hájek

https://doi.org/10.46283/musarch.2021.1.2.02

\section{1. Úvod}

Základní téma této studie směřuje $\mathrm{k}$ možnostem archeologické identifikace elity $\mathrm{v}$ době bronzové. Vycházíme z předpokladu, že ve střední době bronzové ve střední Evropě existovala společenská skupina, kterou můžeme označit jako lokální elita. Elitou se obecně rozumí úzká skupina lidí vyčleněná ze sociálního prostředí, jelikož zaujímá většinou vedoucí úlohu. Toto postavení může být založeno na individuálních vlastnostech, ale též společenském postavení, které pramení např́klad z dědičnosti a rodinných a rodových vazeb (k definici např. Kerbo 2006). Nejčastěji bývá za elitu označována vrstva obyvatel, která koncentruje nejvyšší moc, největší majetek a společenskou prestiž.

Existence elit vychází ze základního předpokladu, že si lidé nejsou rovni, a to ani na biologické úrovni. Z této nerovnosti vychází pririrozeně též společenská nerovnost, a tím rozvrstvení společnosti. To se netýká pouze elity. Ta je jen jednou z hierarchických společenských skupin, které mají kořeny ve společenské specializaci (Neustupný 2010). Důležité je, jakou roli ve vydělení elit hrají artefakty. To totiž ovlivňuje naší schopnost tyto elity identifikovat na základě archeologických pramenů. Jelikož lze elitu považovat za určitý druh specializace, lze předpokládat, že právě artefakty se svým společenským významem hrály důležitou roli ve vymezení této společenské kategorie a v demonstraci jejího společenského postavení. Archeologické doklady existence lokálních elit dělíme tradičně do několika základních skupin. Jedná se o nemovité artefakty spojené se sídlením elit a jejich hrobky, které vykazují mimořádnou 
konstrukci. Z movitých artefaktů to jsou kovové zbraně a šperky, artefakty z drahých kovů a dalších vzácných materiálů (jantar) a také importy. Za významný projev elity je pak považována kumulace většího množství těchto artefaktů v rámci pohřební výbavy (Grömer 2016; Chvojka-Menšík 2017).

Ačkoliv lze v obecné rovině s těmito úvahami souhlasit, existují studie, zaměřené konkrétně na střední dobu bronzovou v Čechách, ukazující, že některé ze zmiňovaných jevů nemusí s elitou souviset. Konkrétně se nepodařilo prokázat souvislost mezi elitou a složitými konstrukcemi a velikostí mohyl (Krištuf - Švejcar 2012; Krištuf - Švejcar - Praumová 2013). Naopak předpoklad o souvislosti bohaté pohřební výbavy a výjimečných artefaktů s pohřby př́íslušníků elity se zdá být pro dobu bronzovou a železnou ve střední Evropě v obecné rovině platný a podporují ho i některé lokálně zaměřené studie (Nožinová - Krištuf 2017). To nám dává možnost pokusit se identifikovat pohřby elity střední doby bronzové na základě bohaté hrobové výbavy obsahující bronzové artefakty a předměty z drahých kovů. $\mathrm{V}$ př́ípadě této studie se zaměříme především na ženské hroby, které jsou typické výskytem bohatých kolekcí bronzových šperků, kterým vévodí náhrdelník (viz níže).

Mohylovou kulturu ve střední době bronzové charakterizuje především pohřbívání pod mohylovými náspy. Z mohyl, většinou prozkoumaných a zdokumentovaných již v 19. století a 1. polovině 20. století, je známo velké množství artefaktů, včetně šperků (např. Jiráñ et al. 2008, 78; 122). Jeden z nejlépe zdokumentovaných souborů středobronzových mohylových hrobů pochází ze západních Čech. Z tohoto důvodu je naše práce zaměřena na pohřebiště Št’áhlavy - Hájek, které patři k největším a nejlépe prozkoumaným mohylovým pohřebištím nejen v západních Čechách. A to i přes to, že bylo prozkoumáno F. X. Francem již v 80. letech 19. století (Šaldová ed. 1988; Cujanová-Jílková 1970). Díky velmi kvalitní dokumentaci můžeme přesně sledovat hrobový inventář i prostorové rozmístění mohyl.

$\mathrm{Na}$ základě těchto dat se pokusíme identifikovat hroby př́slušnic lokální společenské elity na tomto pohřebišti. Zaměříme se na jejich výbavu, ale i konstrukci a prostorovou distribuci mohyl. Naším cílem je představit št'áhlavské pohřebiště jako místo pohřbívání lokální komunity, která byla vertikálně stratifikována, tedy ve které již došlo k etablování lokální elity. Hodláme se zaměřit na testování hypotézy, která předpokládá, že tato elita vztahovala a udržovala svou moc na základě rodinného původu. Společenské postavení tak bylo dědičné.

\section{2. Ženský kroj elity}

Kroj má typické součásti charakterizující společenský status jedince, který sdílí s dalšími členy komunity. Stírá se tak individualita na úkor př́slušnosti ke společenské skupině. Rekonstrukce kroje je tak v archeologii velmi zásadní pro poznání společenského statusu jednotlivců. Jeho součástí naštěstí není pouze oděv, ale i další doplňky, za které považujeme i šperky (např. Kristiansen 2013; Langová 2012). Kolekce těchto šperků se nám daří v archeologických kontextech identifikovat a můžeme se tak pokusit alespoň o částečnou rekonstrukci podoby kroje. V př́padě střední doby bronzové v západních Čechách se ukazuje, že ženský kroj elity byl úzce spjat s náhrdelníky, které bývají doprovázeny dvojicí jehlic, vícero náramky a často též soubory prstenů na rukou i nohou (Nožinová - Krištuf 2017).

Předešlé studie tedy ukázaly, že základní součástí kroje vysoce postavených žen byly náhrdelníky. Bohaté náhrdelníky byly složené ze závěsků (terčovitých se středovým trnem, srdcovitých), spirálek, trubiček nebo korálků. S těmito náhrdelníky velmi úzce souvisejí prsteny, které nacházíme výhradně společně s těmito bohatými kroji. Jejich součástí jsou i další artefakty (jehlice, náramky), které ale nacházíme i v souvislosti s jinými typy krojů, včetně mužských. Nicméně podařilo se prokázat zvýšenou souvislost některých typů těchto artefaktů, právě s bohatým ženským krojem elit.

Jehlice, jako funkční artefakt sloužící pravděpodobně ke spínání oděvu i jako ozdoba, jsou součástí většiny krojů střední doby bronzové. U bohatých pohřbů žen jsou ale nalézány velmi často ve dvojicích. Dále si můžeme povšimnout, že v hrobech, které přisuzujeme společensky významným ženám, se vyskytuje výrazně menší spektrum typů jehlic než u ostatních hrobů. To je pravděpodobně způsobeno tím, že se jedná o úzce a jasně vymezenou společenskou skupinu, zatímco ostatní hroby s jehlicemi, představují množinu různých společenských skupin. Kroj významných žen mohl být velmi uniformní, a proto se projevuje i menší pestrostí typů jehlic. Zdá se, že některé typy jehlic se navíc často vážou právě na tuto společenskou kategorii. Jedná se např́iklad o jehlice se zavinutou, roztepanou nebo spirálovitou hlavicí (Nožinová-Krištuf 2017). 
Běžnou součástí krojů s náhrdelníky jsou též náramky. Nacházejí se vždy na horních končetinách, a to většinou v párech, na každé ruce jeden. Někdy i na každé ruce dva a více. Většinou se jedná o páry stejných typů náramků, které byly nošeny symetricky. Symetrie je důležitou vlastností bohatého ženského kroje. Lze jí spatřovat jak v preferenci dvojice jehlic často stejných typů, tak právě v nošení náramků. Výjimečně se u bohatých krojů žen vyskytuje asymetrické uspořádání náramků (Nožinová - Krištuf 2017). Navíc se u bohatých ženských krojů objevují honosnější typy náramků, a sice náramky žebrované a ploché.

Poslední součástí kroje vysoce postavených žen jsou páskovité a spirálovité prsteny. Nálezy páskovitých prstenů u dolních končetin nasvědčují nošení těchto prstenů výhradně na prstech u nohou. Spirálovité prsteny byly podle uložení nošeny na prstech u rukou. U diskutovaných bohatých hrobů s náhrdelníky se opět vyskytují především ve vyšších počtech (Nožinová - Krištuf 2017).

\section{Pohřebiště Št’áhlavy - Hájek a hroby princezen}

Mohylové pohřebiště Št’áhlavy - Hájek se nachází na západním svahu vyvýšeniny mezi zámkem Kozel a zř́ceninou hradu Lopata jihovýchodně od obce Št'áhlavy (okr. Plzeň-město; obr. 1). Souřadnice pohřebiště v systému S-JTSK jsou X: -811775, Y: -1080405. V 2. polovině 19. století začal s velmi důkladnými systematickými terénními výzkumy mohylových pohřebišt' západních Čech amatérský archeolog František Xaver Franc. Jeho terénní dokumentace slouží k bádání i v dnešní době. Zahrnovala přesné plány, popis nálezových celků i velmi pečlivou kresebnou dokumentaci (Šaldová ed. 1988). Právě mohylové pohřebiště Št’áhlavy - Hájek je prvním systematicky prozkoumaným pohřebištěm v Čechách. Při šestiletém výzkumu pořídil F. X. Franc bohatou dokumentaci. Z celkového počtu 92 mohyl bylo 26 mohyl datováno do střední doby bronzové, 27 náleželo milavečské kultuře a ostatní nebyly datovány. V roce 1959 publikovaly E. Čujanová-Jílková, A. Rybová a V. Šaldová soubor nálezů z tohoto pohřebiště (Jilková-Rybová - Šaldová 1959).

Na mohylovém pohřebišti Št'áhlavy-Hájek bylo tedy identifikováno 92 mohyl. Největší skupina se nachází na terénní hraně, která je o několik metrů převýšená nad okolní terén. $\mathrm{V}$ tomto prostoru je hustota mohyl největší, což je způsobeno především přítomností velkého počtu mohyl menších rozměrů, které náleží milavečské kultuře. Mohyly tvoří protáhlou skupinu ve směru S-J. Další skupina mohyl se nachází západně pod terénní hranou a tvoří ji asi 20 mohyl. V okolí těchto skupin se ještě nachází několik izolovaných mohyl (obr. 2). Přímo v ose největší kumulace mohyl prochází pozůstatky úvozové cesty (Krištuf - Praumová - Švejcar 2011).

$\mathrm{Na}$ lokalitě bylo ve 14 mohylách objeveno 30 hrobů obsahujících celkem 114 šperků ze střední doby bronzové. Hned několik hrobů je vybaveno

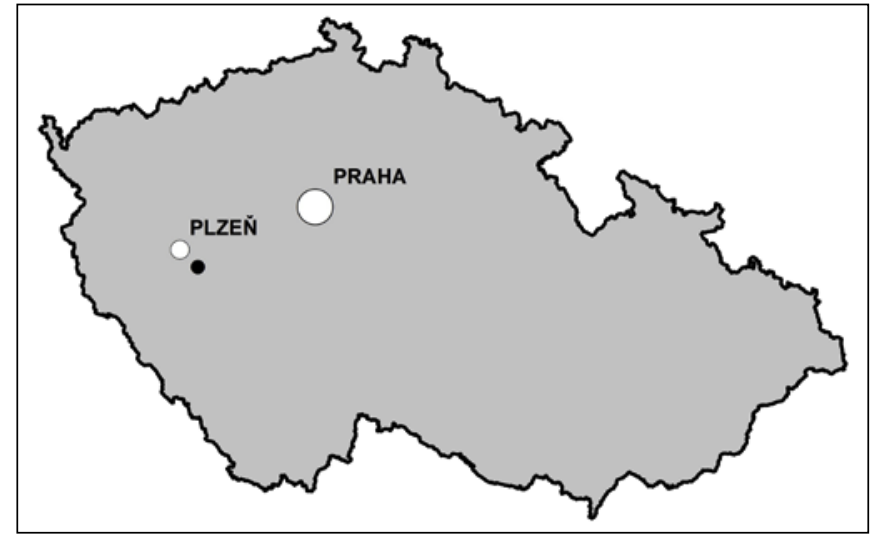

Obr. 1. Lokalizace mohylového pohřebiště Št'áhlavy - Hájek na mapě ČR.

Fig. 1. Location of the barrow cemetery Št'áhlavy - Hájek on the map of the Czech Republic. kolekcí honosných šperků a lze je tedy spojit se skupinou žen, prŕíslušnic lokální elity. Těchto hrobů je 5 , přičemž 4 z nich se nápadně koncentrují v mohyle č. 30 . Tato mohyla obsahovala podle zjištění $\mathrm{F}$. X. France 6 pohřbů, uložených v pěti pohřebních konstrukcích. Centrální kamenná konstrukce, kterou Franc označil číslem 5, byla nalezena prázdná. Je otázkou, zda byla vyloupena nebo zda vůbec pohřeb neobsahovala (viz dále). V okolí této centrální hrobové komory byly objeveny další kamenné pohřební konstrukce, které byly zapuštěny do již existujícího mohylového pláště (obr. 3). Centrální komoru obklopovaly prakticky ze všech stran. Právě v těchto pohřebních komorách byly uloženy pohřby žen s bohatými kolekcemi šperků. Jako nejmladší byl do vrcholu mohyly uložen halštatský hrob vybavený kopím. 


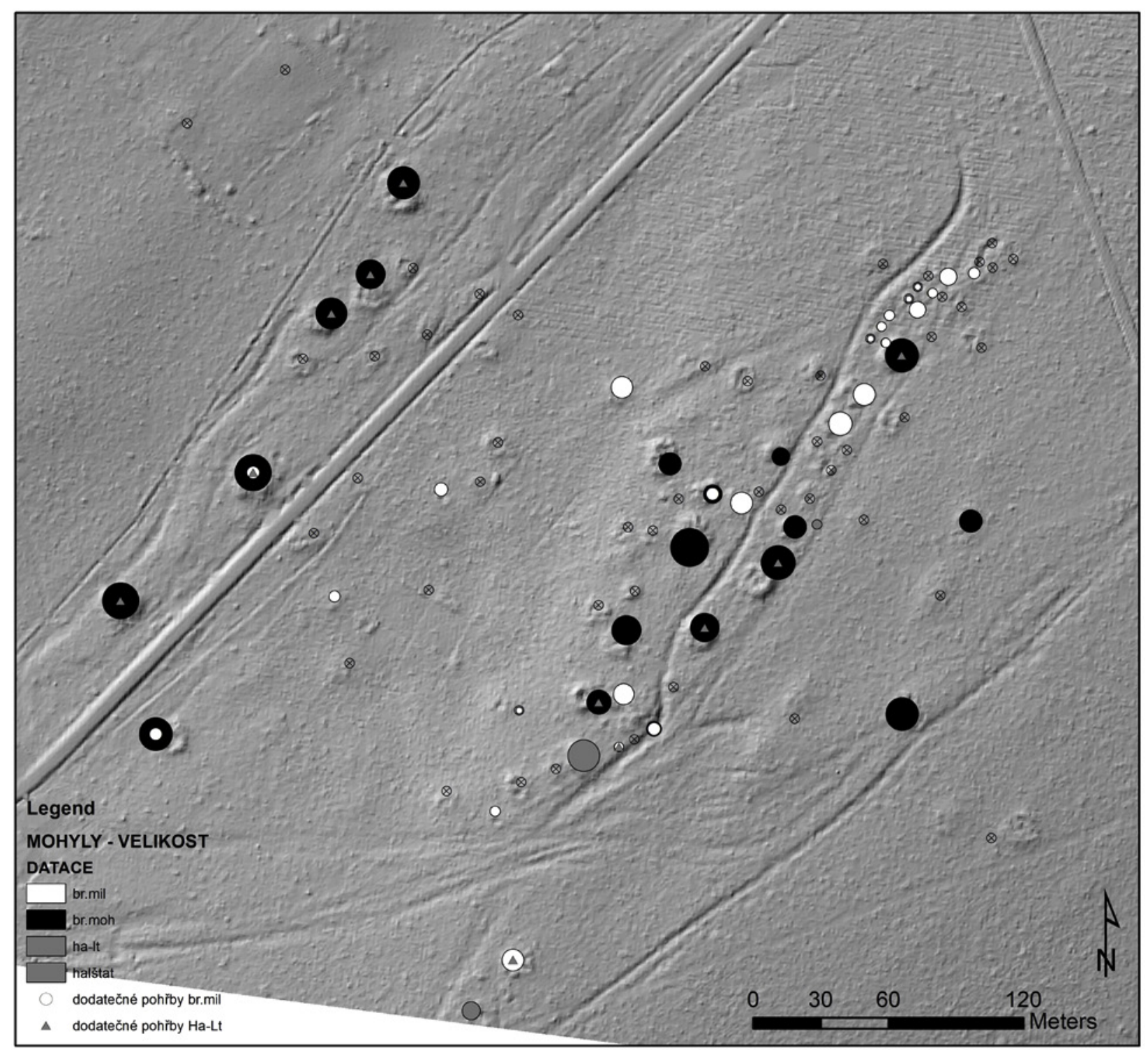

Obr. 2. Plán mohylového pohřebiště Štáhlavy - Hájek podle zaměření F. X. France. Černě - mohyly a pohřby stř̌ední doby bronzové, bíle - mohyly a pohřby mladší doby bronzové, šedě - mohyly a pohřby doby železné. Podkladová mapa na základě dat DMR5g (zdroj: ČUZK).

Fig. 2. Map of the barrow cemetery Št'áhlavy - Hájek according to plan by F. X. France. Black - barrows and burials of the Middle Bronze Age, white - barrows and burials of the Late Bronze Age, grey - barrows and funerals of the Iron Age. Background map based on DMR5g data (source: ČUZK).

Kostrový hrob č. 2 v mohyle 30 je podle pohřební výbavy pravděpodobně ženským hrobem. Na každé ruce byl umístěn jeden tyčinkovitý a jeden žebrovaný náramek. Celkem v hrobě bylo nalezeno čtrnáct prstenů. Osm spirálovitých prstenů bylo nošeno na prstech u rukou. Šest páskovitých prstenů bylo objeveno v oblasti dolních končetin a zachování kostí uvnitř těchto prstenů svědčí o nošení na prstech u nohou. Na každé noze byly nošeny tři páskovité prsteny. V oblasti horní části hrudníku byl nalezen náhrdelník, který sestával ze spirálovitých trubiček, jedenácti jantarových korálků, jedenácti srdcovitých závěsků a pukliček. Náhrdelník byl pravděpodobně tř́ŕradový. Na hrudi byly nalezeny i dvě jehlice s pečetítkovitou hlavicí, jejichž hroty směřovaly vzhưru k lebce. Miska na nožce a amfora byly podle umístění uloženy u nohou (obr. 4).

V mohyle 30 byl dále objeven kostrový hrob č. 3. Pohřební výbava obsahovala dva ploché náramky, nacházející se v oblasti obou horních končetin. Náhrdelník se spirálovitými trubičkami a sedmi terčovitými závěsky byl nalezen 

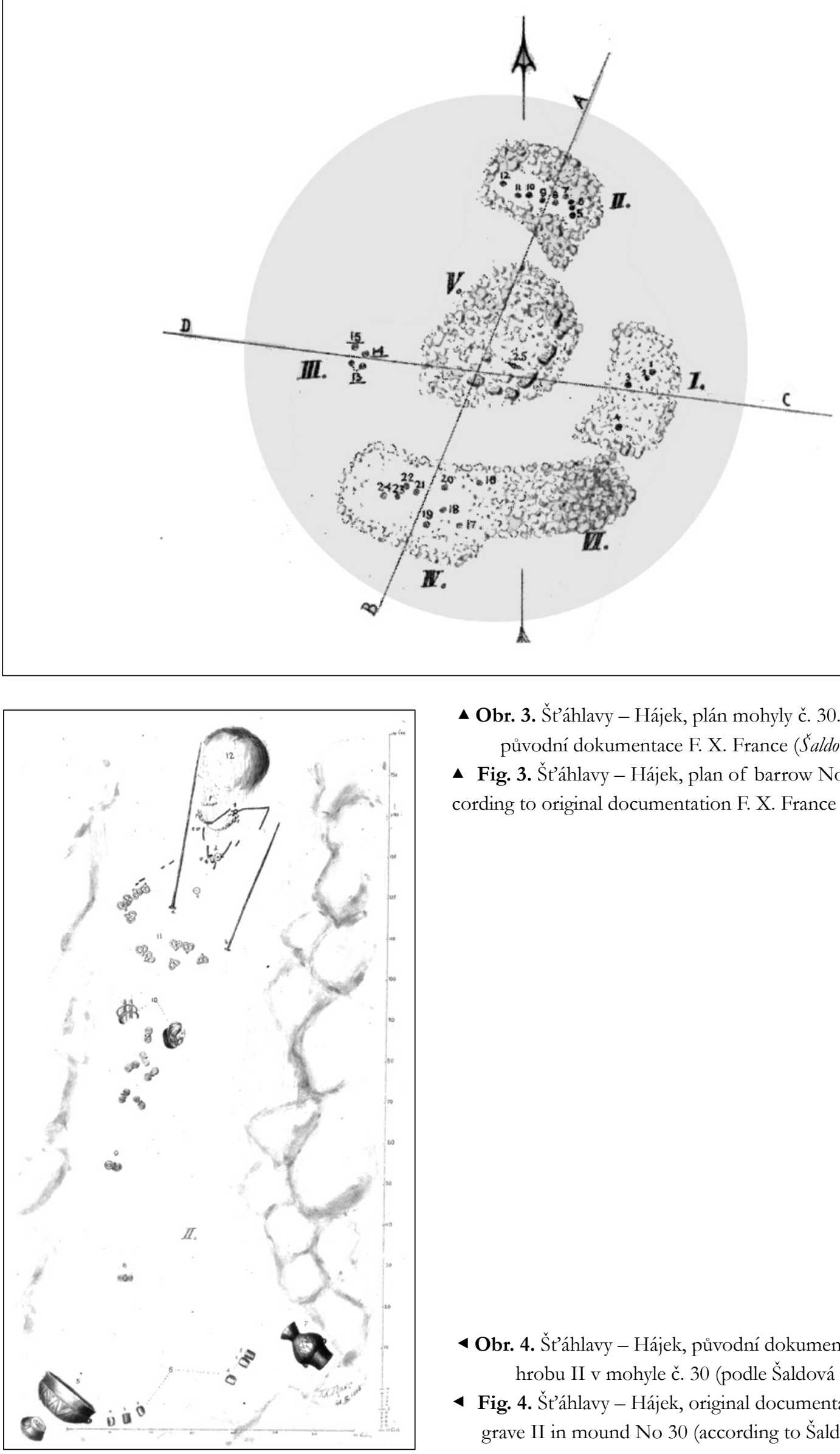

\ Obr. 3. Št’áhlavy - Hájek, plán mohyly č. 30. Upraveno podle původní dokumentace F. X. France (Šaldová ed. 1988).

\ Fig. 3. Št’áhlavy - Hájek, plan of barrow No 30. Modified according to original documentation F. X. France (Šaldová ed. 1988).

4 Obr. 4. Št’áhlavy - Hájek, původní dokumentace F. X. France hrobu II v mohyle č. 30 (podle Šaldová ed. 1988).

4 Fig. 4. Št’áhlavy - Hájek, original documentation F. X. France grave II in mound No 30 (according to Šaldová ed. 1988). 


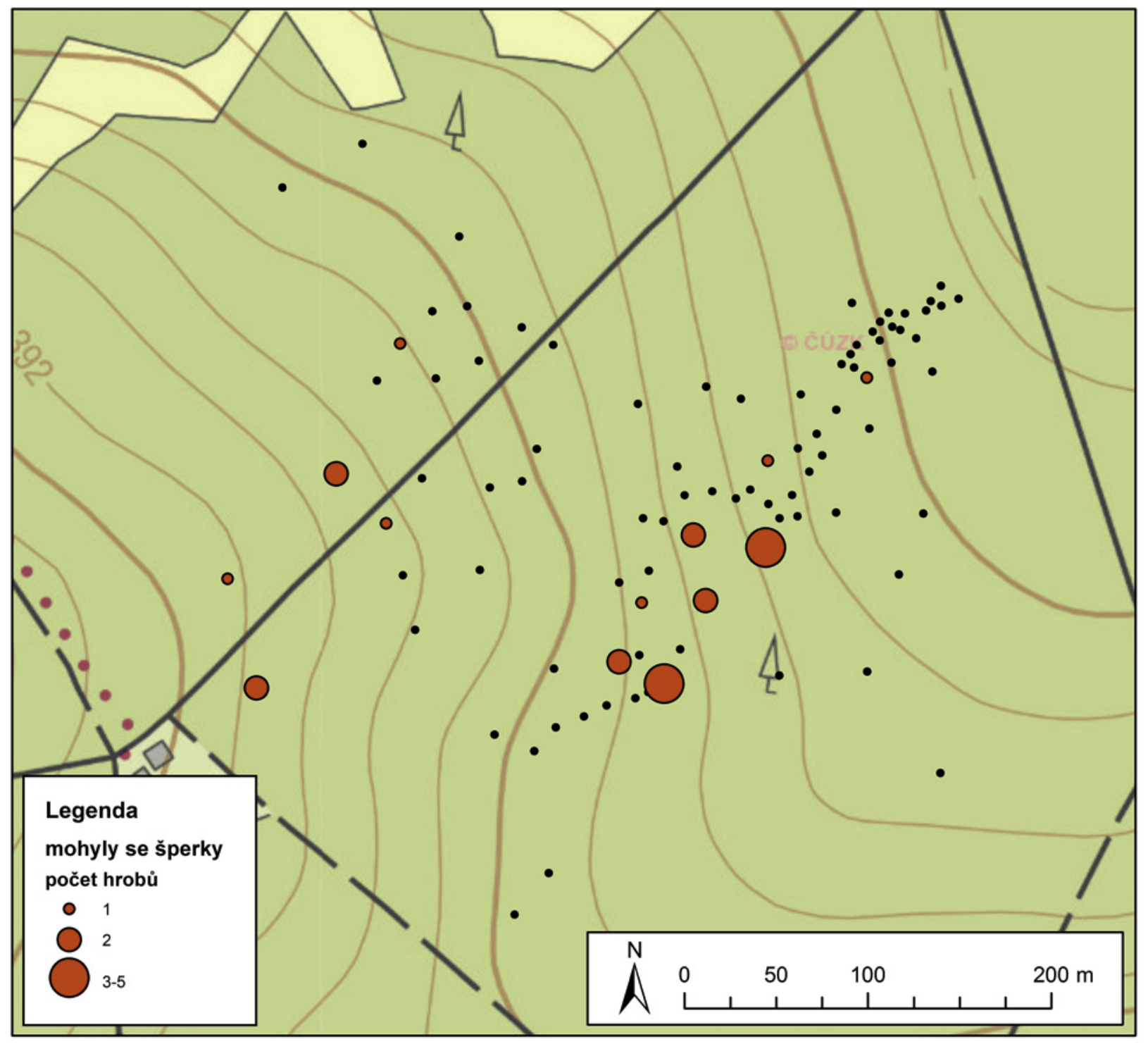

Obr. 5. Št’áhlavy - Hájek, distribuce hrobů se šperky.

Fig. 5. Št'áhlavy - Hájek, distribution of graves with jewellery.

v oblasti lebky a hrudníku. Vedle náhrdelníku byly umístěny dvě terčovité jehlice s hroty směrujícími k hlavě. U hlavy byla nalezena i jedna mísa.

Kostrový hrob č. 4 umístěný opět v mohyle 30 byl pravděpodobně dvojhrob. Podle pohřební výbavy se mohlo jednat o dvě ženy. U prvního zemřelého jedince byly nalezeny dva typy jehlic, které se nacházely v horní části hrudníku, hroty $\mathrm{k}$ lebce. Jedna jehlice byla se spirálovitou hlavicí a druhá s pečetítkovitou hlavicí. V oblasti jedné horní končetiny byly nalezeny dva žebrované náramky se zachovanými kostmi uvnitř a v oblasti druhé horní končetiny byl nalezen náramek se spirálovitými konci. V oblasti horních končetin byly nalezeny také čtyři spirálovité prsteny. V oblasti dolních končetin byly nalezeny tři páskovité prsteny. U druhého zemřelého jedince byl na horní časti hrudníku nalezen náhrdelník. Skládal se ze spirálovitých trubiček a devíti jantarových závěsků. Dále v oblasti horních končetin byly objeveny dva žebrované náramky.

Poslední hrob náleží podle výbavy do skupiny elitních ženských pohřbů jen částečně. V mohyle 14 u něj byly zachyceny spirálovité prsteny a dvojice tyčinkovitých náramků, ale pohřeb obsahoval pouze jednu jehlici s pečetítkovitou hlavicí v oblasti pasu. Náhrdelník chyběl úplně. V oblasti dolních končetin se nacházela mísovitá nádoba a hrnek. Ovšem v oblasti těla byla zachycena koncentrace 150 - 200 bronzových pukliček různé velikosti, které byly alespoň v některých př́padech původně našité na kủži. Jednalo se nejspí̌e o ozdobu šatu (zástěry). Dále byly obje- 


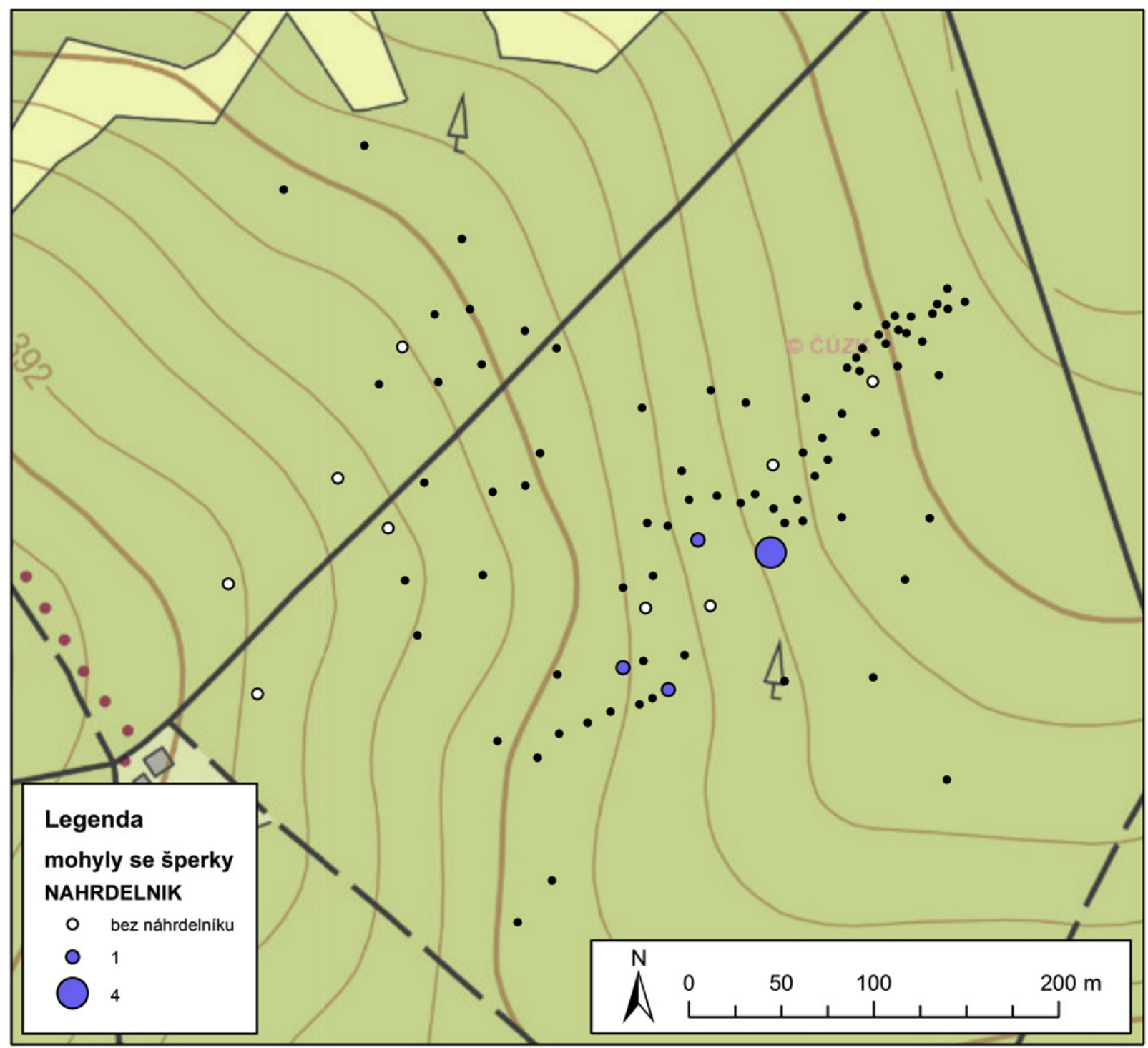

Obr. 6. Št'áhlavy - Hájek, distribuce hrobů s náhrdelníky a závěsky.

Fig. 6. Št'áhlavy - Hájek, distribution of graves with necklaces and pendants.

veny 2 šperky skládající se vždy ze 3 kornoutovitých závěsků, které byly nahoře spojené spirálovitými rourkami. Zde není jasné, zda se jedná o ozdobu šatu, krku nebo třeba vlasů.

\section{Prostorová distribuce hrobů se šperky}

Ve 14 mohylách na pohřebišti byly v pohřební výbavě identifikovány šperky (jehlice, náramky, prsteny, náhrdelníky). Dalo by se říci, že hroby se šperky se nacházejí téměř po celé ploše pohřebiště, nicméně je evidentní, že tyto hroby vytvářejí výraznější koncentraci v jižní části pohřebiště kolem mohyly č. 30 (obr. 5). V této části se též koncertují mohyly, pod kterými se nachází více hrobů se šperky. V 6 mohylách na pohřebišti se nachází 1 hrob obsahující alespoň 1 šperk. V 5 mohylách se nacházejí 2 hroby se šperky a ve 2 mohylách byly nalezeny $3-5$ hrobů se šperky. Obě tyto mohyly se nacházejí $\mathrm{v}$ jižní části pohřebiště. Navíc obsahují hroby, které jsou vybaveny často i několika šperky.

V této jižní části pohřebišsě se navíc koncertují všechny hroby, které jsou vybaveny náhrdelníky či závěsky, které jsou jejich součástí (obr. ๑). Ve třech mohylách zde byl zachycen vždy jeden pohřeb s náhrdelníkem/závěskem. Ale nejzajímavější je mohyla 30, která obsahuje hned 4 hroby vybavené náhrdelníkem. Ostatní 3 mohyly obsahující tyto 
šperky jí obklopuji. Tato výrazná koncentrace svědčí o nenáhodné distribuci takto vybavených hrobů na pohřebišš Št’áhlavy - Hájek. Jediný hrob vybavený srdcovitými závěsky (snad zbytky náhrdelníku), který leží mimo tuto koncentraci, byl objeven v mohyle 27.

\section{Diskuze}

Jak jsme již uvedli výše, předpokládáme, že hlavními prvky ženského elitního kroje jsou náhrdelníky, jehlice, náramky a prsteny na rukou i nohou. Další důležitou vlastností je osová symetrie. Jehlice se objevují v párech, často se jedná o stejné typy. Náramky jsou nalézány ve dvojicích nebo jiných sudých počtech. Nošeny jsou na horních končetinách opět symetricky. To se týká i prstenů, které jsou nalézány na horních i dolních končetinách ve větších počtech. Hroby, které této struktuře odpovídají nejvíce, byly objeveny především v mohyle 30. Jedná se o 4 hroby, kde každému dominuje náhrdelník. Zajímavé je, že každý je zcela jiné konstrukce. V hrobě č. 2 byl nalezen náhrdelník složený ze spirálovitých trubiček, 11 jantarových korálků a 11 srdcovitých závěsků a pukliček. V hrobě č. 3 se jednalo o náhrdelník sestávající ze spirálovitých trubiček, 7 terčovitých závěsků, 1 spirálovitého závěsku a 2 rozřazovačů. V dvojhrobě č. 4 byl u první ženy náhrdelník složený ze spirálovitých trubiček a 9 jantarových závěsků a u druhé sestával náhrdelník ze spirálovitých trubiček a puklice. V ostatních hrobech byly objeveny pouze izolované závěsky nebo jejich zlomky, které mohou též pocházet z náhrdelníků, ale patrně ne tak honosné konstrukce jako v př́padě mohyly 30 . V hrobě v mohyle 14 pravděpodobně náhrdelník zastupuje výjimečný šperk na prsou a těle zemřelé, který je tvořen především puklicovitými nášivkami. Přestože všechny hroby se závěsky jsou doplněny i dalšími šperky, které odkazují na bohatý ženský kroj, hroby v mohyle 30 jsou i v tomto kontextu zcela výjimečné.

Vycházíme z konceptu, že prostorová struktura pohřebišst' doby bronzové je dána př́ibuzenskými vazbami. Tedy, že prostorové shluky mohyl odrážejí společenské jednotky založené na rodinném principu a př́buznosti (Krištuf Švejcar 2012). V takovém př́ípadě lze předpokládat, že prostorově blízké hroby odráží pohřbívání rodiny. Za doklad nejužších společenských či rodinných vazeb se často pokládá pohřbívání do jedné mohyly (Neustupný 1983). Porovnáme-li s tímto modelem prostorové shluky hrobů s náhrdelníky na pohřebišti Št’áhlavy - Hájek musíme konstatovat, že náhrdelníky nebyly běžnou součástí pohřební výbavy všech zde pohřbívajících komunit. Naopak. Shluk hrobů s náhrdelníky v okolí mohyly 30, která sama obsahuje hned několik takto vybavených hrobů naznačuje, že tento typ šperku byl spojen jen s určitou částí komunity, kterou bychom mohli definovat jako rodinu. Jelikož dalším předpokladem je, že náhrdelníky v kombinaci s dalšími šperky jsou znakem společenské elity, můžeme předpokládat, že elitní společenský status byl v komunitách pohřbívajících na Hájku dědičný, tedy spojený s konkrétní rodinou, $\mathrm{v}$ rámci které byl předáván. Tato rodina/komunita pohřbívala na vyvýšeném místě $\mathrm{v}$ jižní části pohřebiště $\mathrm{v}$ mohyle 30 a jejím okolí.

Co to vlastně znamenalo být př́slušnicí lokální elity v době bronzové v západních Čechách? Pokud vyjdeme ze zjištění, že vy̌šši společenské postavení mohlo být dědičné a předávané v rámci jedné rodiny, musíme př̌edpokládat, že vyšší společenské postavení není nutně závislé na osobních vlastnostech jednotlivce. Výše postavené rodiny pravděpodobně dokázali hromadit majetek v podobě artefaktů. Tento majetek jim poskytoval ekonomickou výhodu a přinášel možnosti ovládnutí distribuce surovin a artefaktů. Z toho potom vyplývala jejich moc nad ostatními členy komunity. Množství bronzových artefaktů v hrobech př́slušníkủ elity odkazuje na to, že pravděpodobně sehrávali klíčovou roli ve výrobě a distribuci právě bronzových artefaktů. V mužském světě je toto společenské postavení často spojováno s vrstvou bojovníků, kdy mužská elita se většinou v archeologických pramenech projevuje jako elita bojovnická. Jejich hroby jsou často vybaveny kombinací různých zbraní. U ženských př́slušníků této skupiny není jejich zapojení do struktury společnosti tak zřejmé. Je možné, že měly určitou úlohu v symbolické komunikaci, o čemž by mohla svědčit i honosnost a uniformita jejich kroje.

Nejen že se bohaté hroby princezen na Hájku koncentrují v jedné mohyle, ale zároveň v této mohyle chybí hroby př́slušníků mužské elity. To přiliš neodpovídá výše uvedené představě o koncentraci pohřbívání elity v jižní části pohřebiště. Ani v okolních mohylách nebyly totiž zachyceny hroby, které by bylo možné jednoznačně přisoudit nejvýše postaveným mužům v místní populaci. Snad jen centrální hrob v mohyle 17, který obsahoval bronzovou dýku, sekeru a bohatě zdobenou mísu na nožce, by bylo možné spojit s mužskou bojovnickou elitou. Mohyla 17 je zajímavá i svojí 
polohou. Nachází se totiž v jižní části pohřebiště, která byla ve střední době bronzové využívána poměrně intenzivně, a snad souvisí i s pohřbíváním rodiny, jejíž členové měli výjimečné postavení. Ovšem v těsném okolí této mohyly, nebyly zachyceny žádné další, a to v okruhu asi 25 až 30 metrů. V jinak velké hustotě mohyl v této části pohřebiště působí prázdný prostor kolem mohyly 17 jako anomálie, a mohl by svědčit o zvláštním postavení zde pohřbených jedinců. Ti byli minimálně 4 . Kromě výše zmíněného pohřbu muže se zbraněmi, byl později (stále ve střední době bronzové) přidán pravděpodobně ženský hrob s dvojicí jehlic a tyčinkovitých náramků a kolekcí keramiky. Z doby bronzové je i třetí pohřeb s jehlicí a dvojicí nádob. Posledním identifikovaným pohřbem je halštatský pohřeb bojovníka s kopím, který byl umístěn do vrcholu mohyly. Mohyla byla tedy využívána k pohřbívání poměrně dlouhou dobu, přesto byl prázdný prostor kolem ní stále respektován.

Kde jsou tedy pohřbeni př́slušníci mužské elity? Jelikož tuto vrstvu již tradičně spojujeme se statusem bojovníků, je pohřebiště na Hájku v tomto směru určitou anomálií. I přesto, že se jedná o jedno z nejlépe prozkoumaných mohylových pohřebišt' v Čechách, byly v rámci celého areálu identifikovány pouze 2 hroby se zbraněmi. Např́klad na pohřebišti Sedlec-Hůrka byly objeveny 3 hroby s mečem a hrobů ze zbraní zde bylo identifikováno 8 , což je $57 \%$ z prozkoumaných (Krištuf - Švejcar - Havlikková 2017). Celkově činí hroby se zbraněmi v kontextu střední doby bronzové v západních Čechách $26 \%$. V prípadě 2 hrobů na Hájku je to pouhých $5 \%$. Prvním př́padem je již zmíněný hrob v mohyle 17, který není v kontextu ostatních bojovnických hrobů nikterak výjimečný. Jiným prípadem je druhý bojovnický hrob, který byl objeven $\mathrm{v}$ mohyle 48. Kromě jehlice a bronzové dýky uložené v keramické míse, zde byla nalezena bronzová sekera a především bronzový meč. Kombinace těchto 2 artefaktů je v českém prostředí střední doby bronzové spojena s těmi nejhonosnějšími bojovnickými hroby (Krištuf - Praumová - Švejcar 2011; Havlikevá - Krištuf 2017), a je tedy pravděpodobné, že se jedná o mužské př́íslušníky elity. Nicméně mohyla 48 se nachází v západní mohylové skupině, která je od hlavní koncentrace mohyl oddělena nejen prázdným prostorem, ale i převýšením terénu. S největší pravděpodobností se jedná o místo pohřbívání jiné komunity. Domníváme se tedy, že mužský hrob z mohyly 48 nemá prímou vazbu na ženské hroby v mohyle 30.

Vrat'me se ale ještě $\mathrm{k}$ situaci př́mo $\mathrm{v}$ mohyle 30 . Kromě již několikrát zmíněných 4 bohatých ženských hrobů $\mathrm{s}$ náhrdelníky zde v centrální části $\mathrm{F}$. X. Franc objevil pohřební komoru stavěnou z mohutných kamenů. Kolem ní jsou rozmístěny výše zmíněné hroby, ale samotná centrální komora byla objevena prázdná. Jelikož byla částečně porušena, domnívá se Franc, že mohla být ještě v době bronzové vykradena. Nicméně stejně tak mohla být pouze poničena při budování mladších pohřbů, nebot’ její narušení je minimální. Tato prázdná centrální komora v mohyle elity, by totiž mohla být odpovědí na otázku chybějících mužských hrobů této skupiny. Je totiž možné, že mohyla byla původně zbudována jako kenotaf, tedy prázdný pohřební monument určený pro př́íslušníka elity, který zemřel způsobem, který neumožňoval jeho standardní uložení na rodinném pohřebišti. V př́ípadě mužů/bojovníkủ se nabízí smrt při válečných aktivitách daleko od domova. Jak dnes víme, takovéto střety v Evropě v době bronzové existovaly, a na místě jejich konání dodnes leží ostatky bojovníků, které musejí logicky chybět na lokálních pohřebištích. Navíc napríklad v prípadě bojiště u Tollense je doloženo, že zde zabití bojovníci pocházeli i z poměrně vzdálených regionů, včetně Čech (Price - Frei - Brinker et al. 2017).

Absence mužských elitních hrobů na Hájku by mohla na první pohled svědčit o dominantním postavení žen v místní společnosti doby bronzové. Nicméně pro tento předpoklad nemáme žádné další spolehlivé doklady. Pravděpodobnějš́ je předpoklad, že hroby mužské elity na Hájku prostě chybějí z jiných důvodů, které jsme diskutovali výše. Nicméně můžeme konstatovat, že prúislušnice lokální elity toto své postavení, vyplývající ze sprúiznění s vládnoucí rodinou, demonstrovaly minimálně $\mathrm{v}$ př́padě pohřebního ritu bohatým krojem, jehož dominantní součástí byly vybrané šperky. Na základě studia jiných souborů šperků se navíc zdá, že tyto kolekce nebyly vyráběny pouze pro prriležitostnou demonstraci sociálního postavení, např́iklad během pohřebního ritu, ale že byly běžně nošeny i za života žen (Krištuf - Nožinová 2018).

Poslední zajímavou skutečností, kterou máme v úmyslu diskutovat, je podoba náhrdelníků, jako klíčového atributu ženské elity. Obě ženy uložené $\mathrm{v}$ hrobě IV měly méně honosné náhrdelníky, v jednom př́padě se jednalo o náhrdelník tvořený bronzovými spirálovitými rourkami a jednou bronzovou puklicí a v druhém př́padě tvořilo náhrdelník 9 jantarových perel, které byly opět proloženy bronzovými spirálovitými rourkami. Bohatý náhrdelník ženy z hrobu III byl tvořen 7 bronzovými terčovými závěsky, které byly proloženy bronzovými spirálovitými rourkami. Skládal se pravděpodobně ze 3 šňůr, př̌čemž 2 byly spojeny 2 plechovými obdélnými rozřazovači. Velmi bohatý byl též náhrdelník ženy v hrobě II. Též ho tvořily minimálně 2 šñưry, na kterých bylo zavěšeno 11 bronzových srdco- 


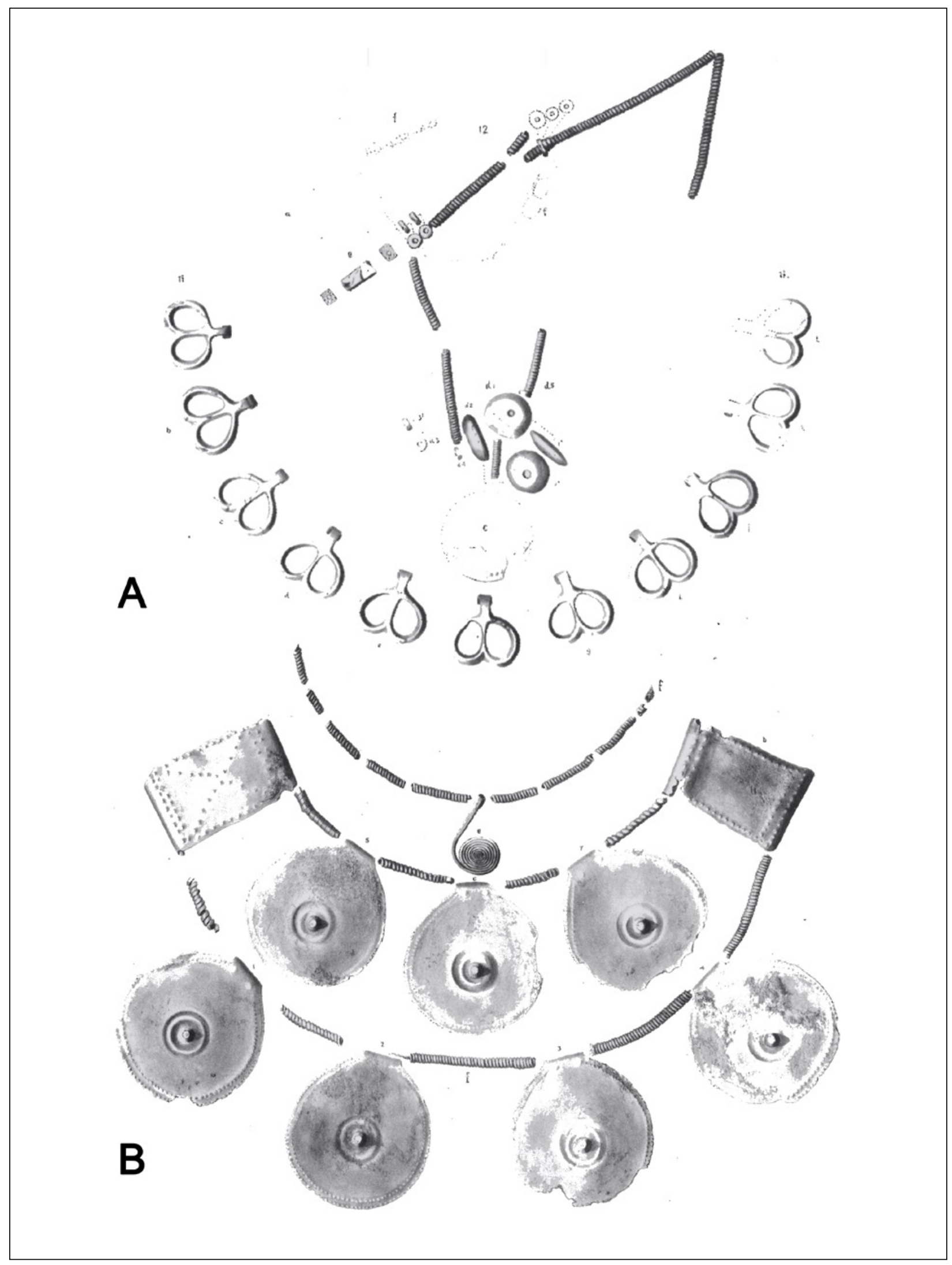

Obr. 7. Št’áhlavy - Hájek, podoba náhrdelníků z hrobů II (A) a III (B) v mohyle č. 30 podle F. X. France (Šaldová ed. 1988).

Fig. 7. Št’áhlavy - Hájek, necklaces from graves II (A) and III (B) in barrow No 30 according to F. X. France (Šaldová ed. 1988). 
vitých závěsků a též 11 jantarových perel, které byly kombinovány s bronzovými spirálovými rourkami a jednou puklicí (obr. 7).

Je zajímavé, že jsou náhrdelníky tak odlišné. I když je třeba upozornit na to, že náhrdelník v hrobě II byl podle nálezové situace pravděpodobně tvořen vnější šňưrou, která byla zdobena srdcovitými závěsky, zatímco vnitřní pak jantarovými perlami, spirálovými rourkami a v centrální části bronzovou puklicí. Tím se tato šňưra výrazně podobá kombinaci obou náhrdelníků z hrobu IV. Spojitost obou žen v hrobě IV je nejvýrazněji deklarována jejich společným uložením $\mathrm{v}$ rámci jedné hrobové komory. $\mathrm{Na}$ základě podobnosti krčního šperku by jsme mohli usuzovat i na souvislost s pohřbem v hrobě II. Hypotézy o podobnosti šperku $\mathrm{v}$ rámci jedné rodiny či komunity byly vysloveny již dř́ve, na základě studia souboru mimo naše území (Bergerbrant 2007).

V této souvislosti je zajímavé sledovat i výskyt podobných typů náhrdelníků v Čechách. Zaměřili jsme se na náhrdelníky se srdcovitými závěsky, terčovými závěsky a jantarovými perlami (obr. 8). Nutno ř́ci, že hlavní koncentrace všech těchto typů leží právě na Plzeňsku. Terčovité náhrdelníky se kromě toho vyskytují v jednom exemplári na Domažlicku a v jednom na Mostecku. Srdcovité náhrdelníky se kromě Plzeňska objevují ve třech prípadech opět na Domažlicku a jeden byl nalezen na Hořovicku. Dva tyto náhrdelníky ale pocházejí i z jižních Čech, konkrétně z okolí Týna nad Vltavou a Bechyně. Jantarové náhrdelníky se opět koncentrují na Plzeňsku (nap̌r. Meclov, Všekary, Žákova). Mimo tento region registrujeme jeden ve středních Čechách na Kladensku a jeden z Mostecka. Tomu odpovídá i obecná koncentrace nálezů jantaru (většinou jednotlivé korálky) ve střední době bronzové v Čechách, kdy nejvýraznější koncentrace leží právě v západních Čechách (Chvojka et al. 2017). To jsou tedy hlavní typy náhrdelníkủ objevených $\mathrm{v}$ mohyle 30 . Ve všech př́padech nacházíme jejich koncentraci převážně v západních Čechách, konkrétně na Plzeňsku. Dalo by se tedy říci, že mohyla 30 leží v centru výskytu těchto šperků ve střední době bronzové v Čechách. Rádi bychom se ale ještě zmínili o jednom typu šperku. Jedná se o 2 kolekce kor-

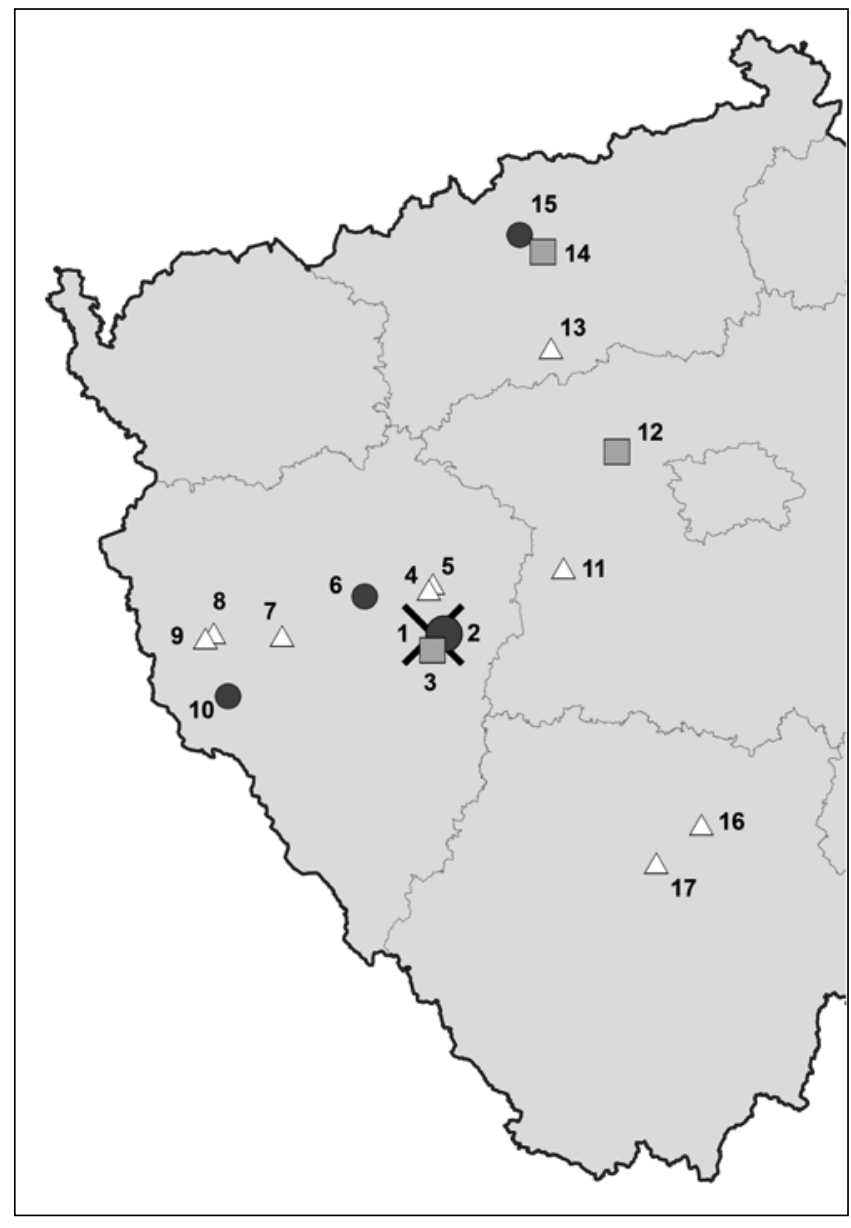

Obr. 8. Distribuce vybraných typů náhrdelníků na území západních, jižních, středních a severních Čech. Trojúhelník - srdcovité závěsky, kroužky - terčovité závěsky (větší značka - 2 náhrdelníky na pohřebišti Milínov-Javor), čtverce - jantarové korálky. 1 - Št'áhlavy - Hájek, 2 - Milínov-Javor, 3 - Žákava, 4 - Ejpovice, 5 - Dýšina, 6 - Vejprnice, 7 - Všekary, 8 - Mělnice, 9 - Mírkovice, 10 - Luženice, 11 Hořovice, 12 - Velká Dobrá, 13 - Lušst'any, 14 - Obrnice, 15 - Kopisty, 16 - Dobronice, 17 - Hosty.

Fig. 8. Distribution of selected necklace types in Western, Southern, Central and Northern Bohemia. Triangle - heart-shaped necklaces, rings - disc-shaped necklaces (larger mark -2 necklaces at Milínov-Javor burial site), squares amber beads. 1 - Št áhlavy - Hájek, 2 - Milínov-Javor, 3 Žákava, 4 - Ejpovice, 5 - Dýšina, 6 - Vejprnice, 7 - Všekary, 8 - Mělnice, 9 - Mírkovice, 10 - Luženice, 11 - Hořovice, 12 - Velká Dobrá, 13 - Lúšt’any, 14 - Obrnice, 15 - Kopisty, 16 - Dobronice, 17 - Hosty. noutovitých závěsků, které byly v trojicích nalezeny v mohyle 14. Tyto kornoutovité závěsky nejsou naopak pro západočeský region typické. Byly registrovány na třech pohřebištích ve středních Čechách a jeden exemplár také v jihočeských Hvožd’anech. Dalo by se tedy říci, že oproti ostatním sledovaným typům náhrdelníků, je tento typ šperku v západních Čechách naprosto ojedinělý. V př́padě hrobu 14 tak můžeme uvažovat, že se jedná svým způsobem o cizorodý prvek v kolekci ženských šperků místní elity. Jedinec by tak mohl mít určité spojení s komunitami mimo Plzeňskou kotlinu. 
Uniformita kolekcí šperků v hrobech ženské elity naznačuje snahu o jednotnou identifikaci těchto žen ke společenské vrstvě. Tento typ identifikace pomocí kroje, který byl zdoben jednotným způsobem nepozorujeme pouze na lokální úrovni na pohřebišti Štéhlavy - Hájek, ale podobné kroje nacházíme i na jiných pohřebištích v západních, jižních a středních Čechách. To by mohlo ukazovat, že společenská elita v rámci širšího regionu o sobě věděla, a pomocí specifických artefaktů deklarovala svou prríslušnost ke společenské vrstvě, která již nebyla založena pouze na principu př́buznosti, ale na principu získaného společenského postavení. Otázkou je, zda jednotlivé typy šperků nemohly v rámci této skupiny ukazovat i na užší vazby mezi elitou v rámci prostoru Čech. Bohužel př́ibuznost nositelek jednotlivých typů náhrdelníků nemůžeme sledovat, a tak tyto úvahy zůstávají v rovinách spekulací, nicméně mohyla 30 na pohřebišti Št'áhlavy - Hájek opět ukazuje svoji výjimečnost, nebot’ se jedná o jedinou mohylu v rámci Čech, kde byly pohřbeni hned 4 jedinci s náhrdelníky a navíc tyto náhrdelníky odkazují minimálně na 3 odlišné styly, které z této doby známe.

\section{Závěr}

Mohylové pohřebiště Št'áhlavy - Hájek vykazuje ve své prostorové struktuře minimálně 2 výrazné koncentrace středobronzových mohyl. Jedna z nich je umístěna na terénní hraně, tedy v dominantní poloze. $\mathrm{V}$ jižní části této skupiny byla zjištěna výrazná kumulace hrobů s bohatými kolekcemi šperků, včetně náhrdelníků, které podle nás představují typickou součást kroje ženské elity střední doby bronzové. Jelikož je pravděpodobné, že prostorová struktura pohřebiště odráží rodinné vazby, spojujeme tuto koncentraci s pohřbíváním lokální elity, která byla založena na př́buzenském principu. Společenské postavení tato elita tedy nezískávala na základě osobních vlastností jednotlivých členů, ale spíše příbuzností nebo dalšími vazbami na privilegovanou rodinu, jejî̌ společenské postavení $\mathrm{s}$ velkou pravděpodobností souviselo s kontrolou produkce bronzových artefaktů, které tvoří klíčovou součást jejich pohřební výbavy.

Nápadná je absence mužských hrobů $\mathrm{v}$ této části pohřebiště. Domníváme se, že toto lze vysvětlit spíše pohřby mužů na jiném místě, než-li dominantním postavením žen. $V$ úvahu připadá i zvýšená úmrtnost mužů v rámci bojovnických akcí mimo region a jejich pohřbení mimo rodinná pohřebiště.

Typologická struktura šperků žen z mohyly 30 ukazuje na vazby elity na větší vzdálenosti a identifikaci jejích členek nejen ke své současné rodině, což je zdưrazněno společným uložením v jedné mohyle, ale též může odkazovat na odlišný původ žen, a tím i výměnu partnerek na větší vzdálenosti, ale stále v rámci privilegované vrstvy. Domníváme se tedy, že lokální elita doby bronzové fungovala na rodinných vazbách a udržovala styky s př́slušníky stejně postavených rodin i mimo svou užši komunitu. To vše ukazuje na společnost fungující již nikoliv na základě rodových či kmenových vazeb. Identita jedince se tak nevztahuje pouze $\mathrm{k}$ rodině, ale též k vyšším celkům, které jsou ovládány právě elitou (Bergerbrant 2007; Felding 2015; Kristiansen - Larsson 2005; Kristiansen - Suchowska-Ducke 2015).

\section{Bibliografie}

Bergerbrant, S. 2007: Bronze Age Identities: Costume, Conflict and Contact in Northern Europe 1600-1300 BC. Stockholm.

Cújanová-Jílková, E. 1970: Mittelbronzezeitliche Hügelgräberfelder in Westböhmen - Západočeská mohylová pohřebiště střední doby bronzové. Praha.

Felding, L. 2015: The Egtved Girl: Travel, Trade and Alliances in the Bronze Age. Adoranten 2015, 5-20.

Grömer, K. 2016: The Art of Prehistoric Textile Making. The development of craft traditions and clothing in Central Europe. Wien.

Havliková, M. - Krištuf, P. 2017: Význam zbraní v pohřebním ritu střední doby bronzové - The importance of weapons in the burial rite of the Middle Bronze Age. Archeologie ve středních Čechách 21, 261-271. 
Chvojka, O. - Chytráček, M. - Metlička, M. - Michálek, J. 2017: Jantar střední až pozdní doby bronzové v Čechách Bernstein der mittleren bis späten Bronzezeit in Böhmen. Památky archeologické 108, 89-120.

Chvojka, O. - Menš̌lk, P. 2017: Možnosti identifikace elit doby bronzové v jižních Čechách na př́kladu výšinných lokalit. Živá archeologie 19, 16-21.

Jilková, E. - Rybová, A. - Šaldová, V. 1959: Mohylové pohřebiště na Hájku u Št’áhlav, okres Plzeň. Památky archeologické 50, 54-119.

Jirán, L. et al. 2008: Archeologie pravěkých Čech/5: Doba bronzová. Praha.

Kerbo, H. R. 2006: Social Stratification and Inequality: Class Conflict in Historical, Comparative and Global Perspectives. New York.

Kristiansen, K. - Larsson, T. B. 2005: The Rise of Bronze Age Society. Travels, Transmissions and Transformations. Cambridge.

Kristiansen, K. 2013: Female Clothing and Jewellery in the Nordic Bronze Age. In: Bergerbrant, S. - Sabatini, S. (eds.): Counterpoint. Essays in Archaeology and Heritage Studies in Honour of Professor. Oxford, 755-769.

Kristiansen, K. - Suchowska-Ducke, P. 2015: Connected Histories: the Dynamics of Bronze Age Interaction and Trade $1500-1100$ bc. Proceedings of the Prehistoric Society 81, 361-392.

Krištuf, P. - Nožinová, S. 2018: Možnosti rekonstrukce kroje doby bronzové na základě analýzy povrchu bronzovách náramků - On the possibility to reconstruct the Bronze Age costume on the basis of analysis of surfaces of bronze bracelets. Archeologické výzkumy v jižních Čechách 31, 87-103.

Krištuf, P. - Praumová, R. - Švejcar, O. 2011: Prostorové uspořádání mohylových pohřebišt’ na Plzeňsku - Spatial structures within barrow cemeteries in Pilsen-region. Acta FF 4/11, 104-128.

Krištuf, P. - Švejcar, O. 2012: Možnosti identifikace rodiny v pravěku na základě studia mohylových pohřebišst' - Identification of family in prehistory based on spatial analysis of cemeteries. Antropowebzin 3, 221-232.

Kristuf, P. - Švejcar, O. - Havlikková, M. 2017: Bojovníci z mohylového pohřebiště Sedlec-Hůrka: př́spěvek k poznání válečnictví doby bronzové - Warriors from the barrow cemetery Sedlec-Hůrka: contribution to the knowledge of Bronze Age warfare. Archeologie západních Čech 12, 16-32.

Kristuf, P. - Švejcar, O. - Praumová, R. 2013: Monumentalita mohyl v době bronzové: odraz rodiny, nobility, genderu nebo kulturní př́śslušnosti - Monumentalität der Grabhügel in der Bronzezeit: Ausdruck der Familie, Nobilität, des Genders oder der kulturellen Zugehörigkeit. Archeologie západních Čech 5, 23-35.

Langová, M. 2012: Sídelní areál doby bronzové v Brandýse nad Labem - objekty s lidskými kosterními pozůstatky. Nepublikovaný rukopis diplomové práce. Ústav pro pravěk a ranou dobu dějinnou UK. Praha.

Neustupný, E. 1983: Demografie pravěkých pohřebišs'. Praha.

Neustupný, E. 2010: Teorie archeologie. Plzeň.

Nožinová, S. - Krištuf. P. 2017: Šperky jako součást kroje střední doby bronzové - Jewellery as part of costume in the Middle Bronze Age, Acta Fakulty filozofické Západočeské univerzity v Plzni 2017, roč. 9, č. 1, 153-172.

Price, T. D. - Frei, R. - Brinker, U. - Lidke, G. - Terberger, T. - Frei, K. M. - Jantzen, D. 2017: Multi-isotope proveniencing of human remains from a Bronze Age battlefield in the Tollense Valley in northeast Germany. Archaeological and Anthropological Sciences 11, 33-49.

Šaldová, V. (ed.) 1988: F. X. Franc: Št'áhlauer Ausgrabungen 1890. Přehled nalezišt' v oblasti Úslavy, Radbuzy, Úhlavy a potoka Klabavky 1906. Praha. 


\section{Summary}

The topic of this study is the possibilities of archaeological identification of the elite in the Bronze Age. We start from the premise that in the middle Bronze Age in Central Europe there was a social group that we can call the local elite. We traditionally divide the archaeological evidence of local elites into a few basic groups. It is the fortified sites of the elite and their tombs that exhibit extraordinary construction. As for the movable artifacts, these are metal weapons and jewellery, artefacts of precious metals and other precious materials (amber), as well as imports. The accumulation of more of these artifacts within the funeral assemblage is considered a significant manifestation of the elite. Therefore we can identify the burials of the Middle Bronze Age elite based on rich grave assemblage containing bronze artifacts and precious metal artifacts. In the case of this study, we will focus primarily on women's graves, which are typical for the rich collections of bronze jewellery dominated by the necklace. In the case of the Middle Bronze Age in Western Bohemia, it turns out that the women's costume of the elite was made of necklaces, a pair of pins, bracelets, and often a set of rings on both hands and feet.

One of the best documented sets of the Bronze Age's barrow cemeteries comes from Western Bohemia. For this reason, our work is focused on the cemetery Št'áhlavy-Hájek, which is one of the largest and best documented barrow cemetery in Western Bohemia. Based on this data, we will attempt to identify the graves of members of the local social elite within this cemetery. We will focus on their assemblage as well as the construction and spatial distribution of the barrows. Our goal is to present this cemetery as a place to bury a local community that has been vertically stratified, in which the local elite has already been established. We test the hypothesis that this elite has related and maintained its power based on family origins. Thus, social status was hereditary.

At the barrow cemetery Št'áhlavy-Hájek, we can identify 2 significant concentrations of Middle Bronze Age's barrows. One of them is located on the dominant place. Significant accumulation of graves with rich collections of jewellery, including necklaces, was found in the southern part of this group. These necklaces represent a typical part of the costume of the female elite of the Middle Bronze Age. We assume the spatial structure of the burial site reflects family ties. We associate this group of graves with a local elite that was based on a kinship. Therefore the social status of this elite stems from kinship or other ties to a privileged family. The social status was probably related to controlling the production of bronze artifacts, which form a key part of their funeral assemblage. At the center of this group is barrow no. 30, which contains 4 graves of women wearing necklaces and other jewellery. This is a very special situation. It is a family-owned tomb of very important women of the local community.

The absence of male graves in this part of the burial ground is striking. We believe this does not point to the dominance of women. Increased mortality among men in off-region combat operations and their burial outside family burial grounds is a possible explanation.

The typological structure of the jewellery of the women of barrow no. 30 shows that members of the elite had ties to more distant regions. They have identified themselves not only with their current family, but also with a supra-regional group of the elite. Differences in the composition of jewellery collections can refer to the different origins of women and thus the exchange of partners between regions. So we believe that the local Bronze Age elite operated on family ties and maintained ties with members of the same-ranking families outside their inner community. The identity of the individual relates not only to the family, but also to the larger groups that are controlled by the elite. 